\title{
Coherence Between Land use and Parking in Sustainable Cities
}

\author{
Klára Macsinka \\ Institute of Civil Engineering, \\ Ybl Miklós Faculty of Architecture and Civil Engineering, Szent István University, Budapest, Hungary \\ macsinka.klara@ybl.szie.hu
}

\begin{abstract}
The article introduces main results of a research about defining parking needs to land use functions on the principles of sustainable mobility. Objective of the research was to find a method of determining differentiated, realistic (and environmentally friendly) parking standards applicable in the practice of urban planning and traffic design. Process of the work is briefly presented. Existing Hungarian practice of determining parking demands for different land use functions and zones is dealt with, pointing out problems, inconsequent issues and necessity of an urgent review. Factors to be taken into consideration (land use type, location within the city structure, accessibility and service level of public transportation system, simultaneity of usage land use zones, etc.) are listed. A model for calculation of realistic parking needs is shown. Needs and possible directions of further research are explained.
\end{abstract}

Keywords: Sustainable mobility, parking standard, land use, accessibility, liveable cities.

\section{INTRODUCTION}

Nowadays parked cars are characteristic elements of the streets in our cities.

Parking became a problem in our private car-based society. Problem for the people who want to park but cannot find parking place. Problem for pedestrians whose place parking cars are taking (especially in inner-cities). Problem for the whole society since traffic generation of any urban area depends on the parking spaces the area offers for private cars and increasing traffic volumes have significant, hardly reparable environmental damages.

How many places are enough? Should we provide for as many parking places as we are able to? Should we cater for or control parking demand? Are current national regulations regarding provision of parking well applicable regardless of locality? These are the questions this article deals with.

Number of parking cars in urban areas is a common problem for all developed countries. One of the instruments government and professionals are trying to battle traffic jams by is parking management. Controlling parking possibilities - on public areas as well as on private 
lands - means that traffic generated by the zone can be reduced by providing fewer parking spaces than we could, that is usually less than the demand. Since generated traffic is estimated on the bases of parking places available on the area, parking standards represent a major factor in generated traffic volume and the environmental and social effect traffic creates.

Couple of years ago in developed countries (and in Hungarian practice still this is the case) parking requirements has been representing a minimum number of parking places a new development had to provide to satisfy parking demands.

Due to the social need of creating better living standards in the cities battling huge volume of traffic, high level of noise, serious air pollution and lot of people moving out of the city, sustainable development and as part of it, sustainable mobility became basic principle of urban planning. Professionals acknowledged that one good instrument of decreasing traffic volume is controlling parking demand, especially on the way of planning land use sustainable. Therefore in parking requirements maximum parking standards took the place of minimum parking standards, pointing out a new way of parking management. Of course social acceptance of the issue was not easy, since people who wanted to use their cars do not like this idea. Usually first results (better environment and living standards in the cities) can convince people and win social acceptance.

Other significant reasons for researching this area are another measure forward sustainable mobility and liveable cities: to determine applicable parking standards in future car-free zones and repartitioning public space which is an inevitable task of the near future.

Sustainable mobility planning applies measures to reduce private car traffic volumes in the interest of making cities more attractive and liveable, decreasing environmental damages and increasing traffic safety. One of the most important instruments is management (and control) of parking demand. Providing less parking places at a facility results a decreased generated traffic volume (and less environmental damages) not only on neighbouring areas but a larger road-network as well.

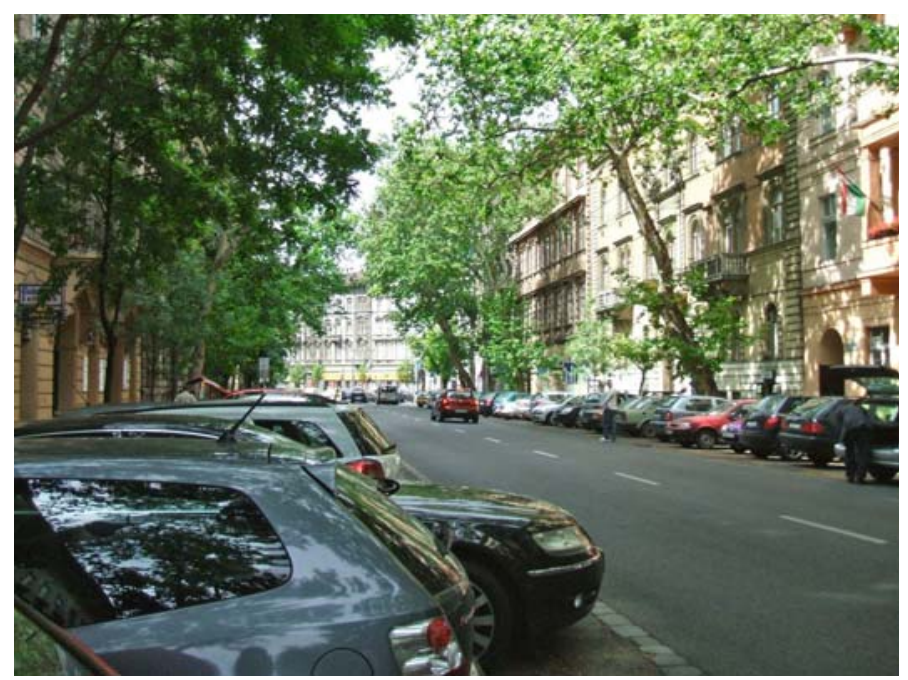

Photo 1 Sharing of public space in Budapest (Podmaniczky street) 


\section{Urban planning and transportation}

During planning development for a settlement primary task is to define and provide infrastructural networks for servicing planned functions. In the complex process of urban development finding solutions to overcome problems in transportation (accessibility, networkconnections, parking) is basic criteria for success. In general cases transportation infrastructure serves ideas for urban development. Structure of settlements is defined by usage, the functions and connections between them. It can be monitored how transportation infrastructure is able to change the structure of a city during urban development, when land use functions are settled next to an infrastructural element using advantage of the infrastructure.

Taking into consideration size, level of development, structure, geographical and social characteristics of a city each and every development can be seen as a unique development. It means that all solutions regarding infrastructure must be (should be) based on special studies and surveys meeting requirements of the actual project. Existing regulation provides limited possibility for special circumstances. Current regulations expect total accommodation of estimated traffic volumes and other transportation needs regardless of function, location, accessibility and other characteristics of a facility.

In the followings the article will introduce existing planning principles in Hungary regarding parking standards and progress, as well as findings of a research on the topic will be shown.

\section{CURRENT SITUATION IN THE HUNGARIAN PRACTICE OF URBAN PLANNING}

In the practice of urban planning parking standards (number of parking places to be provided for a certain land use function, depending on its volume) represent a compulsory element of the design. These values represent minimum number of parking places to be provided for a building. Differing from the regulation has very limited possibilities and planners cannot apply principle of simultaneity either. From ${ }^{\text {st }}$ of January 2013 a new sentence is valid regarding the number of parking places to be provided: these standards are to be kept if local regulations do not say otherwise. There are no further instructions or suggested methods any other assistance for local authorities. This means that from now on if local regulations do not have meet national requirements! Unfortunately this legal solution is not supported by any professional opinion and harmonisation process.

In Hungary parking standards are laid down in Edict 253/1997. (“OTÉK”), about National Requirements on Urban Planning and Building (latest modification in 2012.). For all urban environment parking standards are as follows: 
USE

National minimum parking standard

$1 / m^{2}$ of net floor space unless

otherwise stated

\begin{tabular}{ll}
\hline Residential & 1 parking space $/$ unit \\
\hline Retail & $\begin{array}{l}1 \mathrm{ps} / 10 \mathrm{~m}^{2}\left(\text { up to } 100 \mathrm{~m}^{2}\right) \\
1 \mathrm{ps} / 20 \mathrm{~m}^{2}\end{array}$ \\
\hline Accommodation (hotels, etc.) & $1 \mathrm{ps} / \mathrm{room}$ \\
\hline Restaurants and coffees & $1 \mathrm{ps} / 5 \mathrm{~m}^{2}$ \\
\hline $\begin{array}{l}\text { Education facilities } \\
\text { (Elementary and high schools) }\end{array}$ & $1 \mathrm{ps} / 20 \mathrm{~m}^{2}$ of classrooms \\
\hline $\begin{array}{l}\text { Facilities of tertiary education } \\
\text { Higher \& Further Education }\end{array}$ & $1 \mathrm{ps} / 20 \mathrm{~m}^{2}$ of rooms \\
\hline Cinemas \& conference facilities & $1 / 5$ seats \\
\hline $\begin{array}{l}\text { Other cultural facilities (museums \& art } \\
\text { galleries, etc.) }\end{array}$ & $1 / 50 \mathrm{~m}{ }^{2}$ \\
\hline Sport facilities (stadia) & $1 / 5 \mathrm{seats}$ \\
\hline Service facilities, offices & $1 / 10 \mathrm{~m}^{2}$ \\
\hline Hospitals, health services & $1 \mathrm{ps} / 4 \mathrm{beds}^{2}$ \\
\hline Industrial facilities & $1 \mathrm{ps} / 200 \mathrm{~m}^{2}$ of production rooms \\
\hline Storage facilities & $1 \mathrm{ps} / 500 \mathrm{~m}^{2}$ of storage area \\
\hline $\begin{array}{l}\text { Community green areas (parks, zoo, cemetery) } \\
\text { All other uses }\end{array}$ & $1 \mathrm{ps} / 500 \mathrm{~m}^{2}$ \\
\hline
\end{tabular}

Table 1 Hungarian parking standards [1]

It is possible to deviate from the standards, but only in very limited cases, on the bases of regulations made by local municipalities.

This regulation is to be applied for all areas and all types of development in a city, regardless of the city structure, the existing public transportation network, accessibility of the location or the land use type of the neighbouring areas. The regulation does not include any calculations of generated traffic volumes or possibility to take simultaneity of land use functions. On the other hand other legislation makes it compulsory for large-scale developments to produce an environmental study and a transportation study, so building of new infrastructure serving the new development should be structured on the base of generated traffic volumes. Increase of traffic due to new development is accepted, if the infrastructure can be developed to be able to accommodate extra traffic. It is quite easy to see that this process is not a sustainable one, since as a result an exponential development of road infrastructure and extreme volume of traffic would appear in the cities, where there is no place (or demand) for such a development.

So this process does not only lack sustainability but it is impossible as well. 
There are several other serious questions about existing Hungarian regulation of parking standards [2]:

It is not differentiated enough. Parking standards should be much more differentiated, regarding location of the new development site, its place in the urban structure, accessibility and service level of the road system and the public transport network, social structure of the urban zone, etc.

It is very often not realistic, so does not approach real parking demands. Significant part of transportation section of urban Master Plans is calculation (and valuation) of parking ratio regarding the area. Parking ratio represents the balance (or its lack) between parking demand and provision. Parking demand has to be calculated by the regulation "OTÉK", according to land use type and size (net floor area) of the planned establishment/building. In reality parking demand generated by an existing (or planned) buildings/functions may strongly differ from the number required by the regulation, due to satisfactory accessibility of public transportation or location of the new development within the city structure (for example proximity of a large residential zone, etc.)

Existing parking standard represents a minimum number of parking places, so it does not serve principles of sustainable mobility (following basic idea of not all parking demands to be served), so does not leave much place for reduction of spaces, therefore reduction of traffic volumes. New planning regulation should be made to determine the ratio of the parking demand should we provide for, taking into account characteristics of the city structure.

Location of the planned or existing building is not taken into accounts for calculation of the number of parking places. This factor should be considered from two aspects:

- land use type and size,

- location/position of the facility in the city structure.

Position within the city structure could be characterised by accessibility of the site (by road-network and public transportation network as well as land use type of the neighbouring areas.)

Beside land use type, accessibility is a major factor which traffic generation on an area depends on. Accessibility of the major road-network of the city, distance to public transportation and of course number and service quality of available parking possibilities basically determine the volume of traffic generated by certain facilities.

For example: existing regulations require to implement the same size parking area for a commercial development in a densely built in (sometimes historic) inner city area, where mixed type of land use exists, as if the same facility would be built in an outer zone of the city. In this case it is easy to see that extra traffic is generated in an area (historic city centre), where road infrastructure is usually not suitable to accommodate such a traffic volume.

Besides these areas are usually in need of protection and not further burden. Inner cities usually have good service level of public transportation, so it is realistic to estimate a lower use of private cars (and a better social acceptance of providing less parking places.) 
Another good example about real parking demands exists in residential zones well separated from other land use functions. Families who choose to live in city centres usually have one car or none at all (for example young couples or older citizens), in the same time in low-density residential zones in the outer suburbs families own on an average two, but in numerous times three private cars.

It does not offer any possibility to take into account the fact, that same parking lots may be used for several type of land use in different time of the day (simultaneity). This could happen in any public parking area, where mixed or very closely located land use types exist.

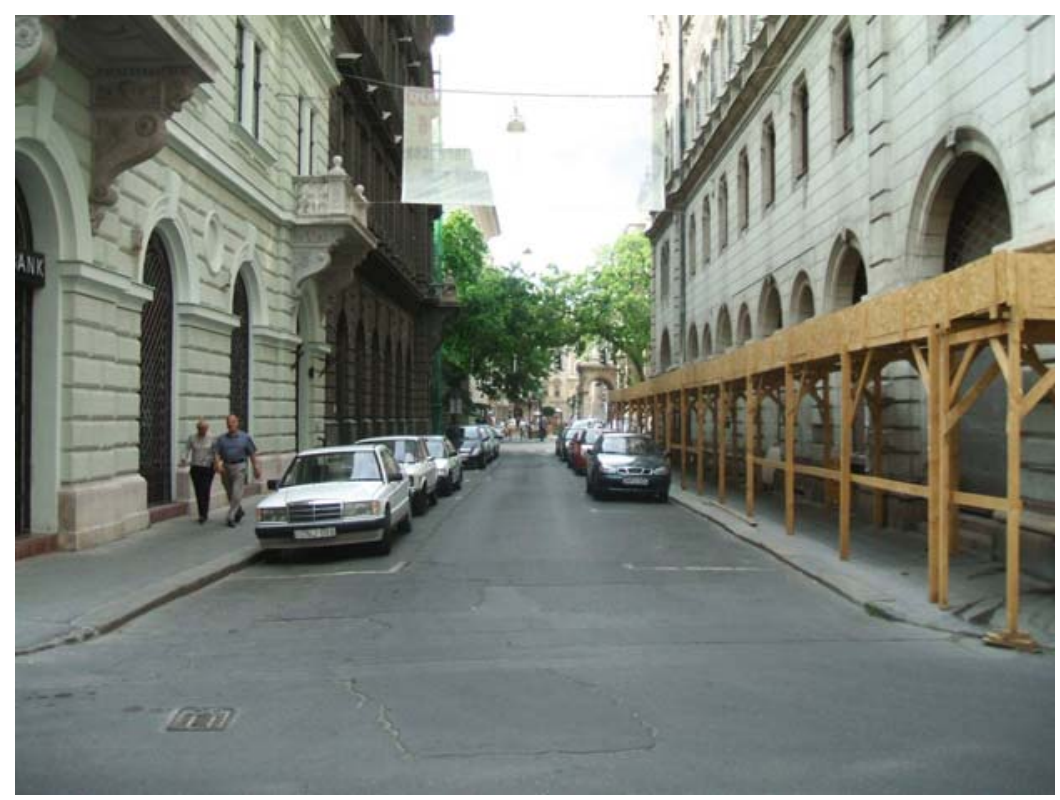

Photo 2 Parking cars taking most of public space

\section{CONTENT, PROCESS AND FINDINGS OF THE RESEARCH}

In the interest of solving problems with parking explained above, a research were conducted with the topic of parking management, one of the key issues in the relation of sustainable mobility and town planning. I worked out a methodology for determining parking needs taking into account principles of sustainable mobility.

Objectives of the research:

- to show that method for calculating the number of parking spaces to be provided to certain land use types or buildings applied in Hungary today is to be modified.

- to define factors to be taken into account in determinations of parking needs to land use functions,

- to study general correspondence and find tendencies between characteristics of land use functions and parking needs created by them,

- to create base for a parking standard system, which is differentiated, realistic and serves 
developing a sustainable urban) transportation system, finding possible reduction in parking standards for different functions and locations, in the interest of lower generated traffic volumes and a safer and better urban environment,

- to work out a methodology to determine realistic parking needs on principles of sustainable mobility and a model that can easily be applied for practical use in the practice of transportation planning and urban design.

\section{Process of the research}

My work contained a review of the international practice for defining parking needs and regulations and ordinances applied in Hungary. To be able to determine factors needed to be taken into account in the methodology of defining parking needs, to work out general correspondences and identifying tendencies, a database was built.

Surveys were done at three levels:

- definition of parking ratio in city centres

- developing a database of $\mathbf{1 7 0}$ buildings and facilities

(representing 8 land use functions) with several characteristics and parameters, like location, accessibility, size and parking balance, located in settlements of different size, with variant infrastructure and network connections. This database can be expanded and supplemented in future researches.

- detailed parking surveys at two university campuses to determine parking characteristics and real parking needs.

Vehicles were identified by last four characters of their registration number, and time of entering and leaving the campus were recorded. [3]

Finally conclusions were drawn from the findings, methodology was worked out and a model was developed for calculating parking needs for each development on the principles of sustainable mobility.

\section{Findings}

Due to the limited extent of this article only some findings can be shown here, pointing out the most important and most interesting results of the research.

\section{International outlook}

Up to the end of the 1990-ies European land use and transport planning practice applied a so-called minimum parking standards. It means that for every new development a minimum number of parking places had to be provided, depending on the function and volume of the development.

For decades transport and land use planning was not too closely related for planners, transportation was there to serve the planned land use development. 
Due to increasing car-ownership, traffic-volumes, congestion and all damaging consequences new planning ideas were thought off and in important two-way connection between land use and transportation was recognised and used as a tool controlling traffic volumes. That was the reason why in the last 15 years European regulations changed to containing parking standards that support sustainable transport and urban planning.

After comparison of the Hungarian regulations to the regulations regarding determination of parking needs it could be shown that Hungarian standards are the strictest among all, they require the highest number of parking places to be provided to land use functions, resulting in significant amount of generated traffic volume. Depending on the land use functions difference between the Hungarian and foreign regulations is generally between $40 \%-70 \%$. The following diagram shows some examples about it.

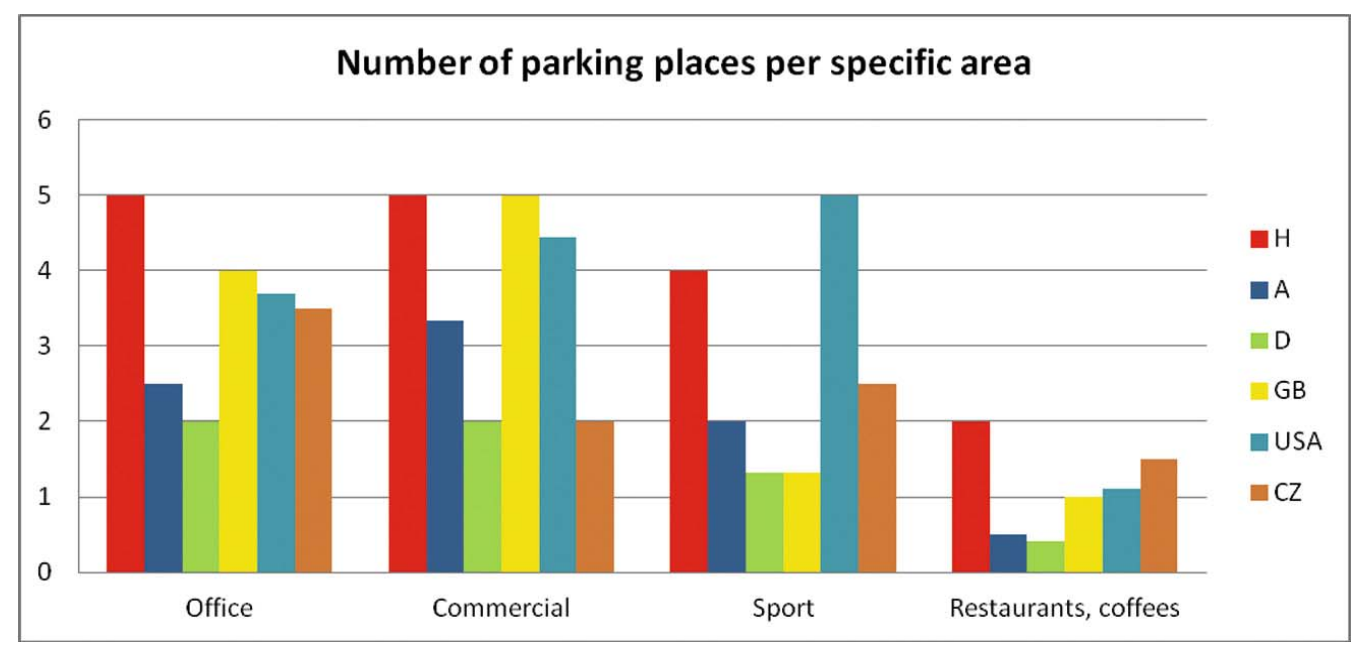

Figure 1 International comparison of parking standards [2]

\section{Parking studies in city centres:}

Parking studies done in city centres showed that at least $75 \%$ of cars use the parking places for short time parking (average parking time: 23 - 70 minutes) and traffic generation on an area might be several times as high as the number of parking places available. Parking balance (ratio between the available and the required number of parking places) were measured to be $15,6 \%$ - $54 \%$ in centres of large cities, $38,8 \%-73,7 \%$ in middle sized cities.

It would be unrealistic to think that required number of parking spaces will ever be built in these central areas that has a dense public transportation network, very narrow public areas and a high volume of (sometimes through) traffic.

As a conclusion it can be said that for buildings and functions located in city centres, maximum number of parking places has to be determined in every case. Reduction factor applies in calculating by standards can be $100 \%$ (criteria must be worked out regarding local 
characteristics). The objective is to reduce traffic volume to a minimum amount and to create a possibility for car free areas. Planners have to keep in mind that providing every single parking place, required by present regulations physically is not possible, not realistic and it is not even desirable.

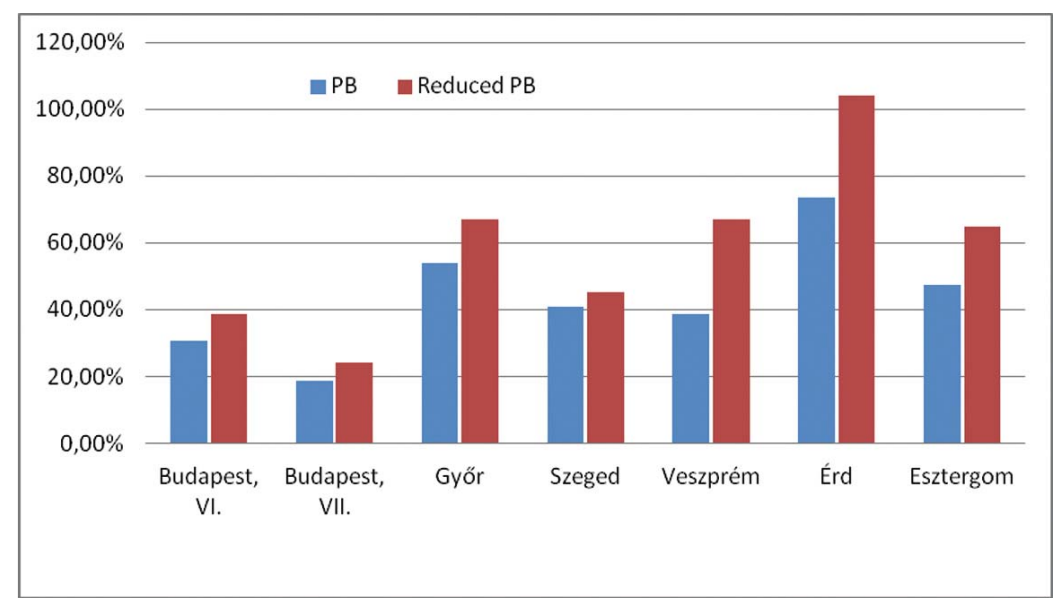

Figure 2 Parking balance values measured in city centres [2]

\section{Parking studies at 170 different facilities:}

Since basic hypothesis during the research was that Hungarian parking standards are not differentiated enough (they do not provide appropriate possibility to take local characteristics into consideration), during assessment of each facility, the following factors regarding features, locality and surrounding were studied:
a) land use function
b) size of the settlement
c) location within the city structure, parameters of the zone
d) road-network on the area
e) accessibility, type and service level of public transportation
f) accessibility by non-motorised modes of transportation
g) parking possibilities on public and private areas,
h) net area and/or capacity of the facility
i) parking needs according to current regulations
j) parking balance (how parking capacity meets requirements) 
The facilities included in the database belong to 9 land use functions and are located in 48 cities. In each settlement I have distinguished three zones (inner city, intermediate and outer zones) and categorised them regarding their accessibility. Evaluation were done on the bases of how existing parking balance change for a certain function as characteristics and environment are modified. Due to the extent of this article, only main findings can be shown.

The next diagram indicates the present parking balance values at the different land use functions included in the study. It is not surprising that built number of parking places exceeds the required amount at commercial functions where investors has primary objective of attracting customers. Increased size of parking area always means higher generated traffic as well.

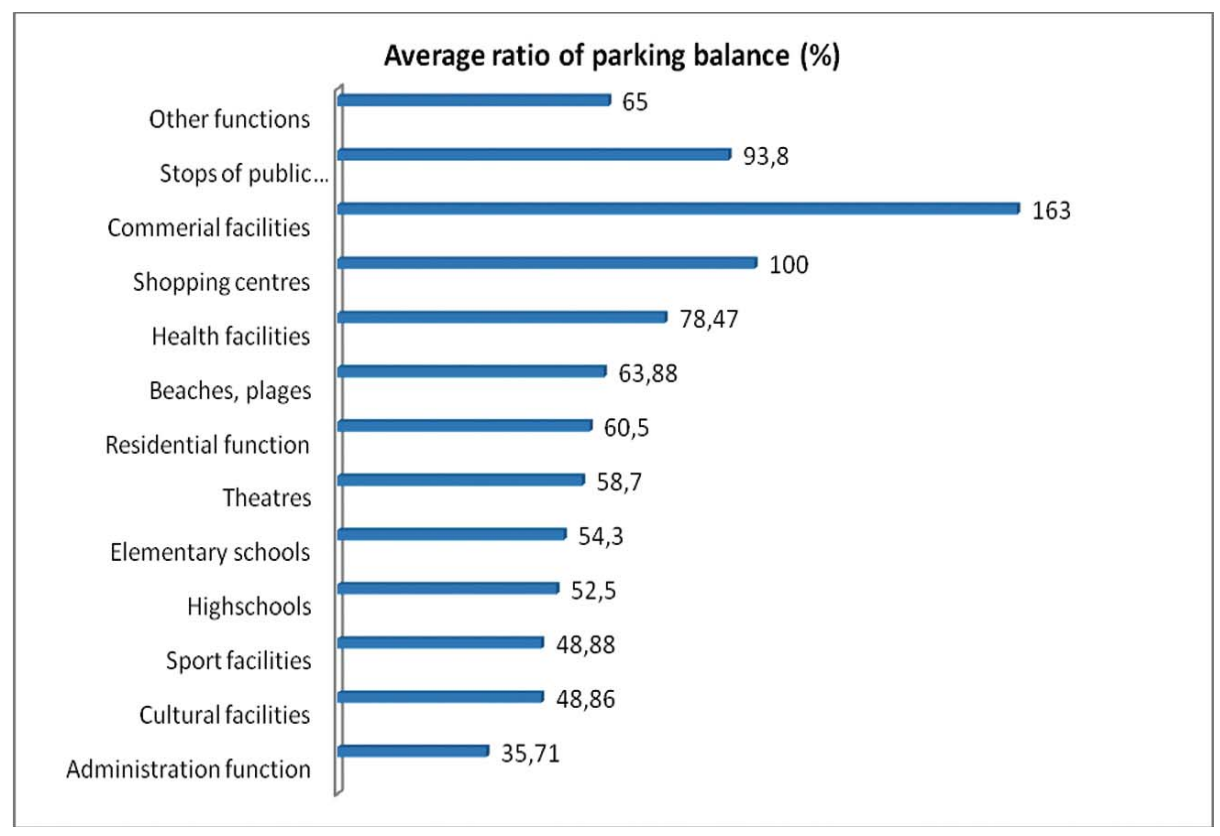

Figure 3 Parking balance values measured in city centres [3]

The detailed research of the different facilities has verified that number of parking places provided for certain functions (realistic and expectable possibility of parking) is closely related to the following factors:

- size of settlement,

- location of site within the city structure,

- accessibility

- size of facility,

- service level of public transportation. 


\section{Parking surveys at university campuses}

In the research I have chosen university campus as a function to be subject of a more detailed survey. A university campus can be examined by itself, clearly, not mixing with other land use functions, so results can be evaluated more accurately.

Two locations were chosen: central campus of Széchenyi István University, Győr and Szent István University, Gödöllö. Apart from the characteristics explained in the above section, number of students and employees, transportation and parking habits were recorded.

Objectives of the surveys:

- obtaining detailed information on parking habits at the institutions

- comparing real (measured) parking needs to required number of parking places,

- determining traffic generation of the parking lots.

\section{Findings}

- Number of parking places required by regulations exceeds real parking needs.

- At both campuses about $\mathbf{7 0} \%$ of the regulated parking needs are real.

- Average parking time is about $\mathbf{3}$ hours and $\mathbf{1 0}$ minutes at both locations,

- Average use of capacity is similar, around $76 \%$.

- Generated traffic volume is $40-46 \%$ of capacity of parking areas.

- Taking into account principles of sustainable mobility and providing other means of transport with a good service level, size of parking lots can be reduced further.

- Special attention should be paid to very short parking periods $(\mathbf{K}+\mathbf{R}$ parking - "Kiss and Ride" short time parking). It needs a separated area (its size depends on size of the university).

\section{NEW RESULTS OF THE RESEARCH}

A) A new evaluation system for accessibility of the sites (facilities) was introduced during the research from the aspects of road network, public transportation and non-motorised modes of transportation. Accessibility of a building and its evaluation is the key-factor in finding a parking standard which is realistic, meets or modify demands based on the principles of sustainable mobility. Accessibility is basic aspect when people choose transportation mode to reach a facility or site. Providing or limiting parking possibilities we are able to influence this decision. Development of sustainable modes of transportation (public, bicycle and pedestrian transportation), increasing their level of service is a condition to reducing parking potential.

The table below shows the qualification system I worked out for evaluating accessibility of a site. All types of accessibility were classified to three categories: excellent, average, poor. 


\begin{tabular}{|c|c|c|c|}
\hline & $\begin{array}{l}\text { Accessibility on } \\
\text { roads }\end{array}$ & $\begin{array}{l}\text { Service level of public } \\
\text { transportation }\end{array}$ & $\begin{array}{l}\text { Accessibility by non- } \\
\text { motorised modes of } \\
\text { transportation }\end{array}$ \\
\hline Excellent & $\begin{array}{l}\text { location by a main } \\
\text { road }\end{array}$ & $\begin{array}{l}\text { Maximum distance from stops: } \\
\text { METRO: } 500 \mathrm{~m} \text {, } \\
\text { tram/bus: } 300 \mathrm{~m} \text {, } \\
\text { safe pedestrian connection, } \\
\text { frequency of vehicles (in peak } \\
\text { hours): } 15 \text { minutes }\end{array}$ & $\begin{array}{l}\text { cycling infrastructure } \\
\text { is within } 300 \mathrm{~m} \text {, or } \\
\text { the road is suitable } \\
\text { for cycling, safe } \\
\text { pedestrian connections } \\
\text { towards stops of public } \\
\text { transportation }\end{array}$ \\
\hline Average & $\begin{array}{l}\text { location by a collector } \\
\text { road }\end{array}$ & $\begin{array}{l}\text { Maximum distance from stops: } \\
\text { METRO: } 500-1000 \mathrm{~m} \text {, } \\
\text { tram/bus: } 300-600 \mathrm{~m} \text {, } \\
\text { frequency of vehicles: min. } 30 \\
\text { minutes }\end{array}$ & $\begin{array}{l}\text { cycling infrastructure } \\
\text { is missing, but the road } \\
\text { is suitable for cycling, } \\
\text { pedestrian infrastructure } \\
\text { is sufficient }\end{array}$ \\
\hline Poor & $\begin{array}{l}\text { location by a service } \\
\text { road }\end{array}$ & $\begin{array}{l}\text { only bus stop is accessible, } \\
\text { pedestrian pavement is missing or } \\
\text { narrow }\end{array}$ & $\begin{array}{l}\text { next to a main road } \\
\text { loaded with heavy } \\
\text { traffic volumes, cycling } \\
\text { infrastructure is missing, } \\
\text { pedestrian connections } \\
\text { are incomplete }\end{array}$ \\
\hline
\end{tabular}

Table 2 Qualification system of accessibility applied [2]

Regarding aspects of sustainable mobility, parking needs can be decreased if:

- accessibility by road is not excellent (because in this case usage of cars is not attractive),

- service level of public transportation is excellent or average,

- accessibility by non-motorised modes of transport is excellent.

In case of cycling and pedestrian connection with qualification of average, reduction factors cannot be applied and if they have poor qualifications even a small increase can be justified.

\section{B) Creating sub-functions of land use}

My research showed that in the case of certain land use functions further classification was needed to provide opportunity for taking into consideration of different characteristics of usage and terminating oversupply of parking which results in increasing traffic volumes. 
a) In case of commercial functions, the following sub-categories were introduced:

- food retails,

- other (non-food) retail,

- shopping centres.

Extension of classification was needed due to different usage and variation of transportation characteristics of the distinct types of commercial facilities. In case of the studied commercial functions the rate of the parking balance was $100 \%$ at shopping centres and $163 \%$ (!) at shops. Changes in the values generally do not depend on the location within the city structure, but in small cities oversupply of parking places is measured and at these shops accessibility by public transportation is usually excellent or at least average.

b) The following sub-categories were introduced in the group of educational institutions:

- child care, kindergarten,

- elementary school,

- high school.

The reason of establishing sub-categories is due to the fact that users of the different types of educational institutions have strongly differing transportation habits. In the last 10 years a significant growth has shown in the number of parents driving their children to kindergarten or child care centres. Short time parking (15-20 minutes) is typical at these facilities. In case of elementary schools smaller parking demands can be measured, K+R ("Kiss and Ride" - short time parking) parking places are needed. At high schools parking standards can be further decreased, parking needs of employees should mostly be served. Application of maximum number of parking places can be justified.

According to my research number of parking places provided at educational institutes currently shows $52-54 \%$ of the requirements.

c) In case of sporting and bathing facilities the following sub-categories were introduced:

- stadia (sport facilities with spectator terrace),

- sports ground without spectator terrace,

- bathes, plages (beaches).

Sub-classification was needed due to the strongly different usage and transportation characteristics of sporting grounds, playing fields, stadia, gymnasia, bathes and plages. In case of the sporting grounds with spectator terrace the generated traffic (and the parking demand) is typically rarely occurs but has a very high volume. Demands are not limited to certain periods of the day, so traffic generation can occur on weekdays or weekends as well, so decreasing number of parking places is more tolerable.

At sporting grounds without spectator terrace a lower volume of generated traffic is expected and parking demands are smaller than in the previous case. 
In case of bathes and beaches generation of traffic and parking situation is significantly different to the needs at sporting grounds. The reason is in the usage of bathes, since they generally provide seasonal service usually in daytime.

As basic information about these facilities area of the bath or plage is given and not the number of people who can be accommodated at one time. Of course fact is that these two data is closely related. So according to these findings it can be declared that realistic determination of parking needs has to be done on different bases in cases if sporting and bathing facilities....

During the study of the sporting functions I found that the average rate of parking balance was $48.88 \%$ and this value was $63.88 \%$ at bathes. [2]

d) In the category of so-called "other" land use function I emphasised the office function, since they are large scale facilities having specific characteristics of usage and usually accommodate significant number of employees and can generate high volume of traffic. In the last 10 years many multi-storey office buildings were constructed in Hungary having serious effect on transportation systems in cities.

\section{D) Method (model) for determining parking needs}

According to the general findings and tendencies I have worked out a model to determine number of parking places (acceptable parking demand) to be built for certain facilities and buildings.

The model represents a framework, it can be extended and modified. The values of parking standards built in the model can be modified and refined according to results of further research. A user applying the model will be able to determine number of parking places for a facility by a special methodology. The model contains all factors of transportation, town planning and technical characteristics which was discussed above.

\section{General steps of the model (method)}

1. Determining land use function and parking standard

2. Determining sub-function

3. Determining size of the settlement

4. Determining zone within the city structure

5. Qualifying service level of public transportation

6. Qualifying accessibility of site on the road network

7. Qualifying accessibility by non-motorised modes of transportation

8. Determining number of parking places - on the bases of reduction factors

9. Checking volume of generated traffic

10. Taking into consideration simultaneity (usage of same parking place at different times)

11. Determining final number of parking places 


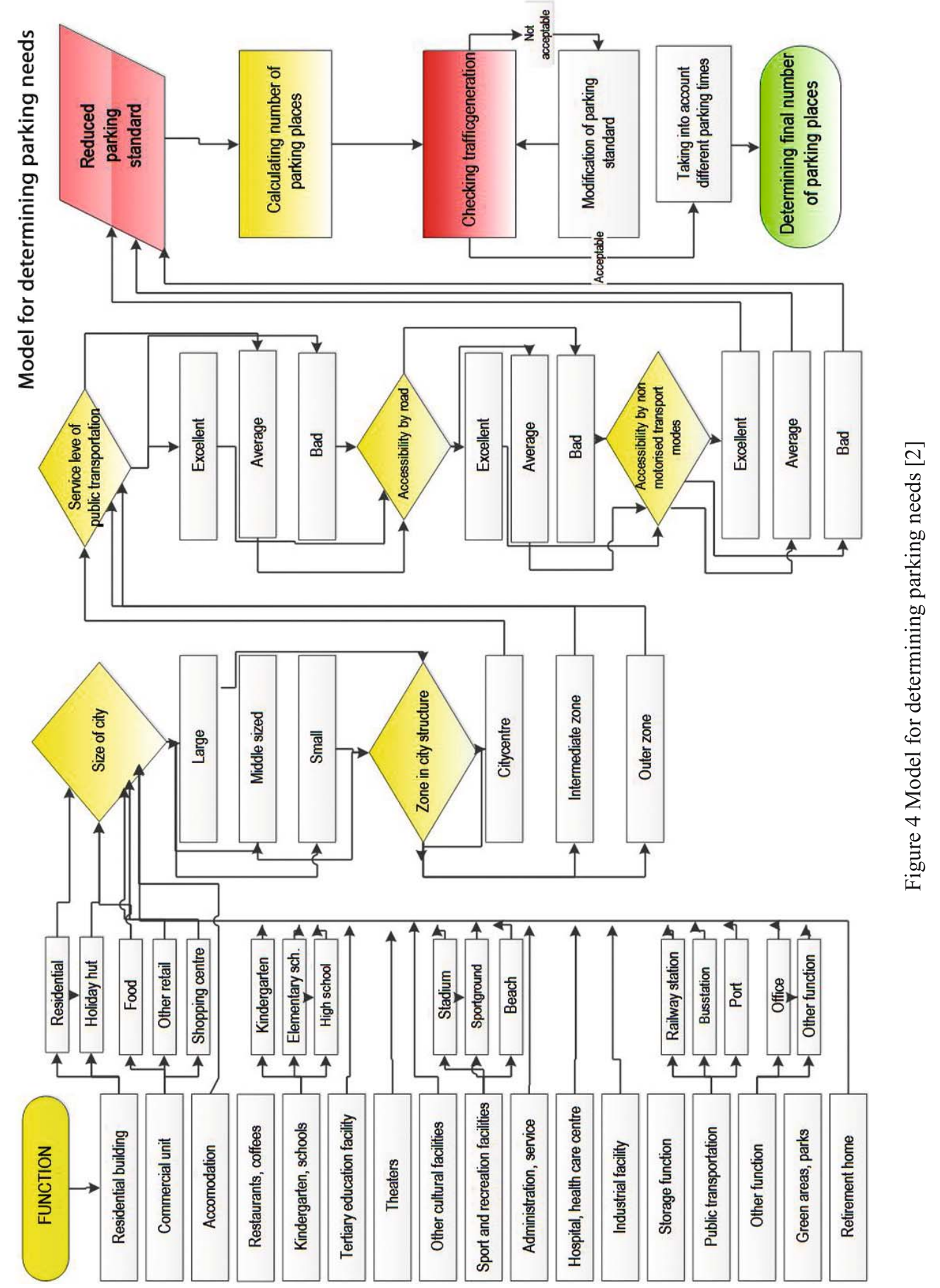


The following summary table contains modified multiplication factors suggested by the research.

\begin{tabular}{|c|c|c|}
\hline \multirow{2}{*}{ Land use function, characteristic } & \multicolumn{2}{|c|}{ Extent of change } \\
\hline & (Sub)function & Reduction factor \\
\hline residential & & 1,5 \\
\hline \multirow{4}{*}{$\begin{array}{l}\text { commercial } \\
\text { introduced sub-functions }\end{array}$} & food retail & 0,67 \\
\hline & non-food retail & 0,5 \\
\hline & shopping centre & 0,4 \\
\hline & $\begin{array}{l}\text { maximum number of } \\
\text { parking places }\end{array}$ & 1,1 \\
\hline \multirow{3}{*}{$\begin{array}{l}\text { child care, kindergarten, elementary and } \\
\text { high schools }\end{array}$} & child care, kindergarten & 0,5 \\
\hline & elementary school & 0,33 \\
\hline & high school & 0,25 \\
\hline introduced sub-functions & \multicolumn{2}{|c|}{ Minimum number of parking places $=5 \mathrm{pp}$} \\
\hline \multirow{3}{*}{$\begin{array}{l}\text { sport facilities, strands } \\
\text { introduced sub-functions }\end{array}$} & stadium & 1,0 \\
\hline & sporting ground & 0,5 \\
\hline & strand & $1 \mathrm{pp} / 25 \mathrm{~m}^{2}$ net area \\
\hline administration buildings & & 0,5 \\
\hline \multirow[t]{2}{*}{ facilities of public transportation } & $\begin{array}{l}\text { Railway station up to } \\
\text { population of } 30.000 \\
\text { (towns in commuter belt) }\end{array}$ & $\begin{array}{l}2,0 \\
6.0\end{array}$ \\
\hline & $\begin{array}{l}\text { At bus stops in the commuter } \\
\text { belt }\end{array}$ & $1,5-2,0$ \\
\hline other functions introduced sub-functions & office building & 0,5 \\
\hline \multirow{3}{*}{$\begin{array}{l}\text { size of settlement } \\
3 \text { categories }\end{array}$} & small town & 1,00 \\
\hline & medium town & 0,8 \\
\hline & large city & 0,85 \\
\hline \multirow{3}{*}{$\begin{array}{l}\text { structural zone within the settlement } \\
\qquad 3 \text { categories }\end{array}$} & city centre & $0-0,5$ \\
\hline & intermediate zone & $0,8-1,0$ \\
\hline & outer zone & $0,8-1,1$ \\
\hline \multirow{3}{*}{$\begin{array}{l}\text { service level of public transportation } \\
\qquad 3 \text { categories }\end{array}$} & excellent & 0,8 \\
\hline & intermediate/average & 0,9 \\
\hline & poor & 1,0 \\
\hline \multirow{3}{*}{$\begin{array}{l}\text { accessibility on roads } \\
3 \text { categories }\end{array}$} & excellent & 1,0 \\
\hline & intermediate/average & 0,9 \\
\hline & poor & 0,85 \\
\hline \multirow{3}{*}{$\begin{array}{c}\text { accessibility by non-motorised modes of } \\
\text { transportation } \\
3 \text { categories }\end{array}$} & excellent & 0,85 \\
\hline & intermediate/average & 0,9 \\
\hline & poor & 1,0 \\
\hline
\end{tabular}

Table 3 Recommended reduction factors in parking standards [2] 
Land use functions which are not shown in the table above were not included in the research, future study must be conducted to present detailed surveys and to recommend reduction in parking standards for those functions as well.

The method of determining number of parking places is system-oriented. It takes into consideration local characteristics of the facility in question, capacity of the surrounding road network, traffic generation of the planned parking area and makes these features influence the number of parking places to be provided.

The model I worked out is able to determine and modify parking standards on the principles of sustainable mobility and it can be generally used easily in planning and operating practice.

The method is based on the following principles:

- providing for all parking needs cannot be primary objective,

- estimating generated traffic volume is crucial, development of road infrastructure is not the only solution in every cases. Principles of sustainable mobility has to become priority in case of determining parking needs in the interest of environmental protection and liveability of the city,

- determining parking needs for certain facilities has to be a process which takes local characteristics into account in a differentiated mode.

In the interest of the above principles the method contains:

- differentiated mode of calculation,

- maximum number of parking places is introduced,

- deviation from the parking standards is possible (decreasing or minimally increasing)

- taking into consideration principles of simultaneity.

The model is able to guide the user through simple steps to determine parking standard to be applied and find the number of parking places to be provided. Basic principle is to find possibilities to decrease number of parking places. In the method there is a step where the model asks for checking capacity of the nearby road network and number of parking places is modified according to the result.

\section{CONCLUSION}

According to the findings and results introduced above, looks like that existing Hungarian regulation regarding parking standards needs a review as soon as possible. This is well underlined by urban planning practice and the international overview.

What are the major factors the modification should address first? 
1. Apart from the minimum standards, maximum ones to be used as well.

2. Differentiation of parking standard on the bases of city-structure, road-infrastructure, public transport network, land use of neighbouring areas, etc. must be worked out (followingnational recommendations, details should be developed locally).

3. Possible reductions in parking standard should have a greater range (car-free areas, test-areas, etc.)

4. Guidelines should be worked out to assist application of simultaneity.

Complexity of the process to develop is undeniable. In almost all cases a special survey should be done and issues need to be carefully considered, so the studied area can be put into the right category. But some general outlines can be (and must be) drawn in every city.

For example:

- All cities can be divided into at least three main zones: inner city, intermediate zone, outerzone (suburbs). So location within the city structure could be first determined by using a local classification.

- Road network in all cities are (or should be) evaluated on the bases of connection to the major road network, capacity-reserve, accessibility of a certain site (by travel time, speed and safety).

- Public transportation network should be evaluated on the bases of vicinity and accessibility, density of the network, timing and comfort of the vehicles.

- Accessibility by non-motorised modes of transportation must be considered at all sites in question.

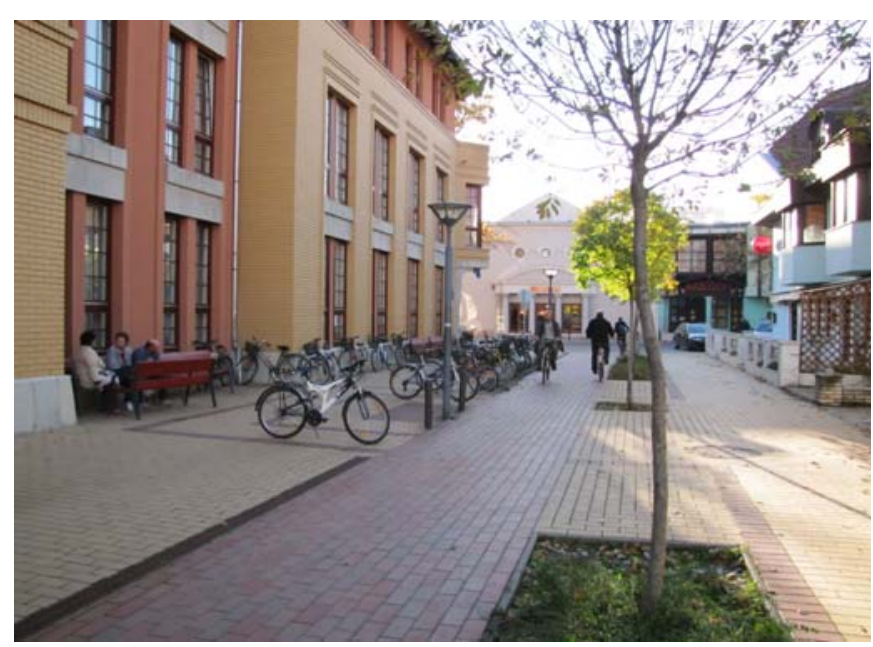

Photo 3 Cycling street at the city of Békéscsaba 
Of course, relation and working together of the city zones, having different or even mixed land use types indicates further aspects to be taken into account. It is very rear that one land use type can be studied "clearly", independently from other neighbouring zones and land use types, therefore determining real parking demands is a complex process.

Besides the number of parking places to be provided for certain developments, regulation should cater for exceptions of the rules, bicycle and bus parking, social aspects of parking and location of the planned parking areas. The issue of location of planned parking lots significant mainly from the viewpoint of urban planning. Locating most of the parking places in parking garages or multi-storey car parks leaves public areas for the use of other community purpose.

Another significant aspect pointing out the need for modification of the existing parking standards is a new trend in urban and transportation planning: basic principles of sustainable mobility.

The research tried to find a professionally suitable and acceptable method to modify parking standards. The model has to be kept flexible and accessible, so new result can be applied, defined reduction factors can be introduced.

Further research can be done in several scientific and professional areas to refine the model (and reduction factors) by adding new data to the database. Complex work of experts from the areas of civil and transportation engineering, urban planning, sociology is needed to find the suitable solution to determine new parking standards for the urban planning and transportation planning practice, more differentiated, realistic and better serving needs for sustainable mobility than the existing ones.

Most important factor during modification of the parking standards is to find a good balance between demands and provision, but principles have to be very clear throughout the process: major goal is to develop a sustainable, liveable city.

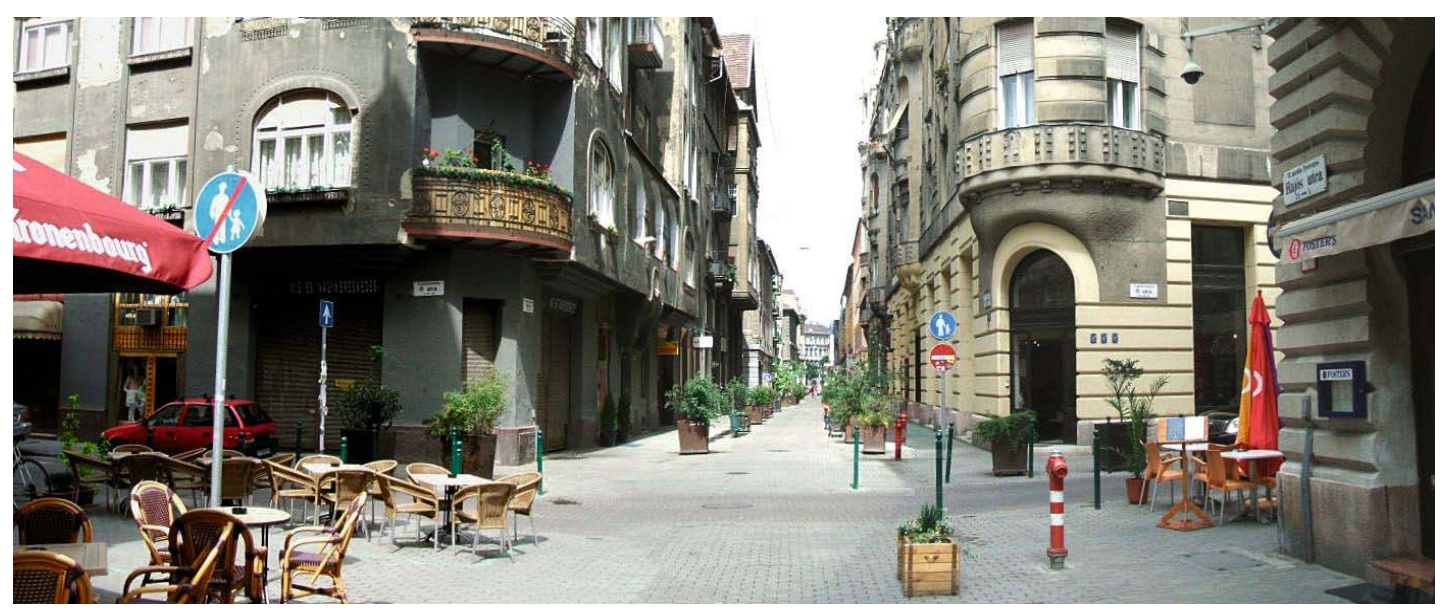

Photo 4 Pedestrian street (Budapest, inner city) 


\section{REFERENCES}

[1] Edict 253/1997. (“OTÉK”), about National Requirements on Urban Planning and Building (latest modification in 2012.).

[2] Macsinka, K. Methodology to determine parking needs to land use functions, based on the principles of sustainable mobility, PHD thesis, Győr, (2012).

[3] Macsinka, K. „Sustainable mobility and historic city centres ” - „Transport infrastructure in Cities” International Conference, University of Zilina, Slovakia (2012), PP. 35-36. 